\title{
Research on the Urbanization of Rural Settlement in City Outskirt in China
}

\author{
Yue Liu1,2, Su Li2 ${ }^{*}$ \\ ${ }^{1}$ Architectural and Urban Planning Design \& Research Institute, Huazhong University of Science and Technology, Wuhan, China \\ ${ }^{2}$ School of Art and Architecture, Central South University, Changsha, China \\ Email:918393723@qq.com, *475119640@qq.com
}

How to cite this paper: Liu, Y. and $\mathrm{Li}, \mathrm{S}$. (2017) Research on the Urbanization of Rural Settlement in City Outskirt in China. Open Journal of Social Sciences, 5, 37-50. https://doi.org/10.4236/jss.2017.53005

Received: February 17, 2017

Accepted: March 13, 2017

Published: March 16, 2017

Copyright $\odot 2017$ by authors and Scientific Research Publishing Inc. This work is licensed under the Creative Commons Attribution International License (CC BY 4.0).

http://creativecommons.org/licenses/by/4.0/

\begin{abstract}
Rapid urbanization in China makes construction and management of city outskirts a hot spot of the society. Empirically, this paper compares characteristics of city outskirt rural settlements before and after urbanization from the aspects of society, facilities and intentions for settlement, thus pointing out features of changing during the urbanization of rural settlements in city outskirt, and puts forward solutions and proposals in terms of coping with the low-position challenges and soft environment construction under the background of the new trends.
\end{abstract}

\section{Keywords}

China, City Outskirt, Rural Settlement, Urbanization

\section{Introduction}

Today, China enjoys the rapidest urbanization in the world. City outskirts are at the forefront of city development. Rapid expansion of cities makes social problems in city outskirts increasingly intensified and prominent, which makes city outskirts the center of secondary contradictions. Resettlement and development of prior rural residents in the outskirts have always been focused on by all relevant parties. Since the 3rd Plenary Session of 18th CPC (2013.11), a series of deep transformations represented by urban land economic transformation and transformation of collective ownership of land have been poised [1]. As the foundation, understanding and study of the current position of rural settlements in urbanized areas seem more necessary.

City outskirt rural settlements can generally be classified into two categories by the form of existence: primitive villages which basically keep characteristics of traditional rural settlements by keeping the land ownership, personnel structure and management unaffected by great changes due to urbanization; resettled ${ }^{*}$ Corresponding author. 
areas, generally referred to as "villages in city", featuring new and special rural settlements in which land property remains unchanged, while farm land is missing and personnel structure and management have also changed.

In the past two decades, among prior researches on city outskirt rural settlements, most are on "villages in city", with the research areas including such aspects as evolution and dynamic mechanisms, environment and social issues, transformation modes and policies as well as extensive and rich contents [2] [3] [4] [5] [6]. The existing researches place emphasis on empirical case study, but it is worth noting that most of them are from the perspective of "post-urbanization" while researches from two perspectives, "pre-urbanization and post-urbanization", are not frequently seen.

Two settlements of the city outskirt, share the same geographical background, but differ by the urbanization process [7], which respectively represent two forms of settlements before and after urbanization, thus providing perfect samples for study on urbanization. On the basis of conducting research on these two kinds of city outskirt rural settlements, this paper compares the differences of rural settlements before and after urbanization, from which we can have a clearer view of urbanization processes, characteristics and shortcomings of former rural settlements, and a deeper understanding of position and appeals of people in rural settlements, thus providing references for relevant planning, construction management and policy making processes.

\section{Data}

Rural settlements during December of 2015 around Yuelu Mountain, Changsha City, Hunan Province, China, are chosen for empirical study. Three unresettled rural settlements, Houhu Village, Taohua Village and Chashan Village respectively; and three resettled communities: Tianma resettled community, Jinjiang resettled community and Science \& Education South resettled community respectively are included. There are 390 households in unsettled area, with total population of 1705 , including 1570 permanent residents and 135 tenants. There are 438 households in the resettled area (resettled households), with total population of 4568, including 1743 permanent residents and 2825 tenants.

Questionnaire method is used to conduct the survey from such three aspects as society, facilities and intentions for settlement. The questionnaire consists of 10 items. The survey content in the aspect of society includes occupation, income, education and other conditions; that in the aspect of facilities includes building area and degree of satisfaction, with the latter covering two aspectsresidential environment (e.g. residence, infrastructures, traffic, environmental health, and service facilities) and social environment (e.g. neighborhood, social security, and organizational management); and that in the aspect of intentions for settlement includes three perspectives-"Areas where residents are most willing to live", "The most important issues in relocation", and "The largest obstacle to job hunting after being identified as citizens". 
As this paper aims to investigate the differences of the original residents before and after urbanization, nonlocal tenants are not included in the survey. The questionnaires are distributed according to the proportion of permanent resident population, with 500 questionnaires distributed and 469 valid ones returned, including 362 for rural settlement and 207 for "villages in city" (Table 1).

\section{Comparison of Rural Settlements before and after Urbanization}

Based on the survey data, two-way comparative analysis on rural settlement (unresettled) and "villages in city" (resettled) before and after urbanization from the three aspects of society, facilities and intentions for settlement is conducted.

\subsection{Society Level}

\subsubsection{Occupational Status}

1) Employment

Figure 1 shows that unsettled residents generally are mostly engaged in agriculture, up to $48.7 \%$. However, proportions of secondary industry and tertiary industry are also high, which indicates that farmers in outskirts are more nonagriculture oriented than farmers in ordinary villages. After resettlement, employments in secondary and tertiary industries don't change substantially. The unemployment rate is increased to $46.7 \%$, which means most of the farmers who worked exclusively in the first industry before resettlement are now unemployed. Resettlement hasn't promoted job transformation. Meanwhile, such a high unemployment rate is unfavorable for social stability.

2) Part-time jobs

Some outskirt farmers have certain part-time jobs. Figure 2 shows that for both resettled and unresettled farmers, among the tertiary industry, the section with highest proportion is part-time work (including decoration, building construction, maintenance, etc.), accounting for $69.8 \%$, followed by business, because college campus is nearby and a lot of service work is needed. These jobs are of low technical contents and unstable. Secondary industry, urban businesses and institutions that are comparatively stable and of high technical contents take low proportions.

Table 1. Distribution of questionnaires.

\begin{tabular}{|c|c|c|c|c|c|c|c|c|}
\hline \multirow{2}{*}{ Total } & \multicolumn{3}{|c|}{ Unresettled area } & \multicolumn{5}{|c|}{ Resettled area } \\
\hline & Houhu & Taohua & Chashan & Tianma & Jinjiang & Science \& & Education South & Total \\
\hline $\begin{array}{c}\text { Number of } \\
\text { questionnaires }\end{array}$ & 65 & 76 & 81 & 82 & 78 & & 87 & 469 \\
\hline $\begin{array}{l}\text { Proportion of } \\
\text { questionnaires }\end{array}$ & \multicolumn{3}{|c|}{$47.3 \%$} & \multicolumn{4}{|c|}{$52.7 \%$} & $100 \%$ \\
\hline $\begin{array}{l}\text { Number of } \\
\text { households }\end{array}$ & \multicolumn{3}{|c|}{390} & \multicolumn{4}{|c|}{438} & 828 \\
\hline $\begin{array}{c}\text { Number of } \\
\text { permanent residents }\end{array}$ & \multicolumn{3}{|c|}{1570 (plus 135 tenants) } & \multicolumn{4}{|c|}{1743 (plus 2825 tenants) } & 3313 \\
\hline
\end{tabular}




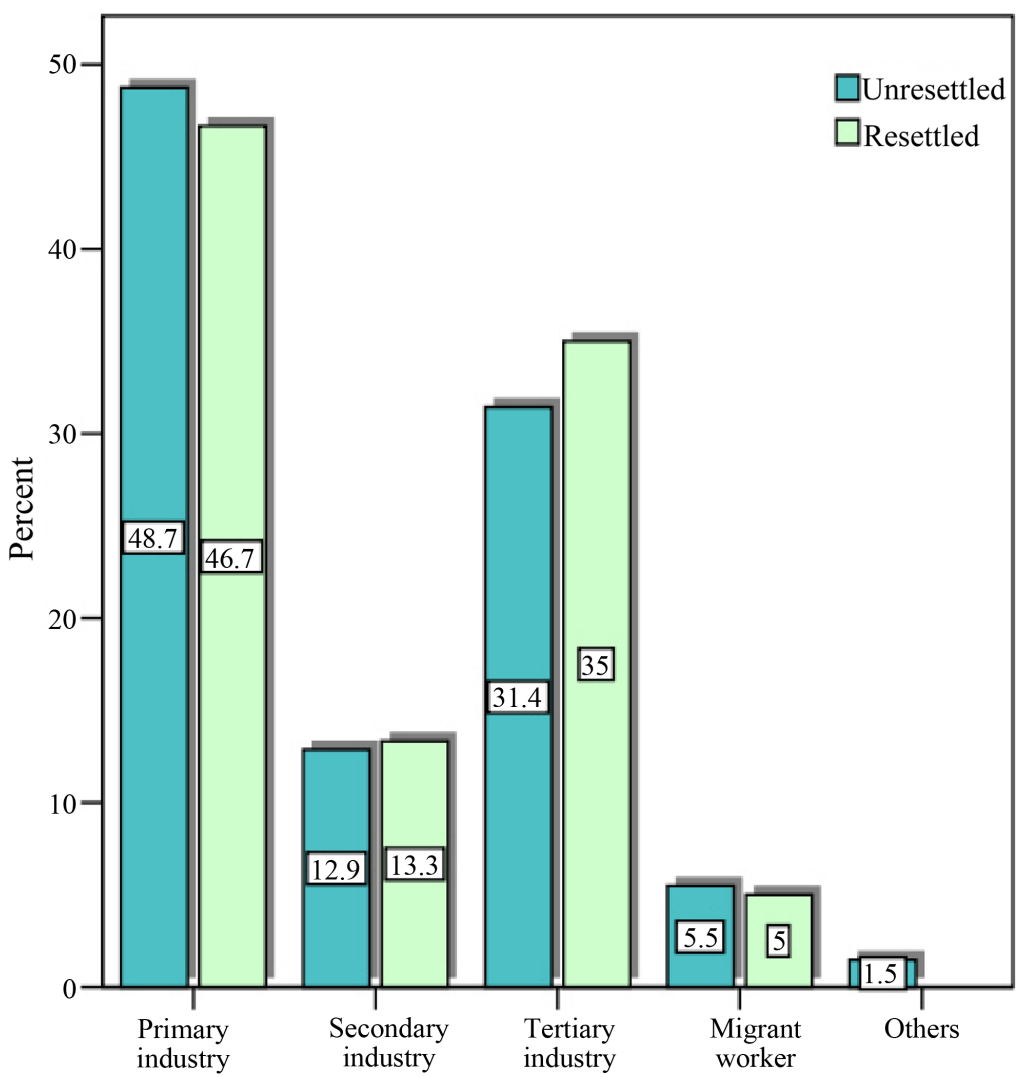

Figure 1. Engaging industry conditions.

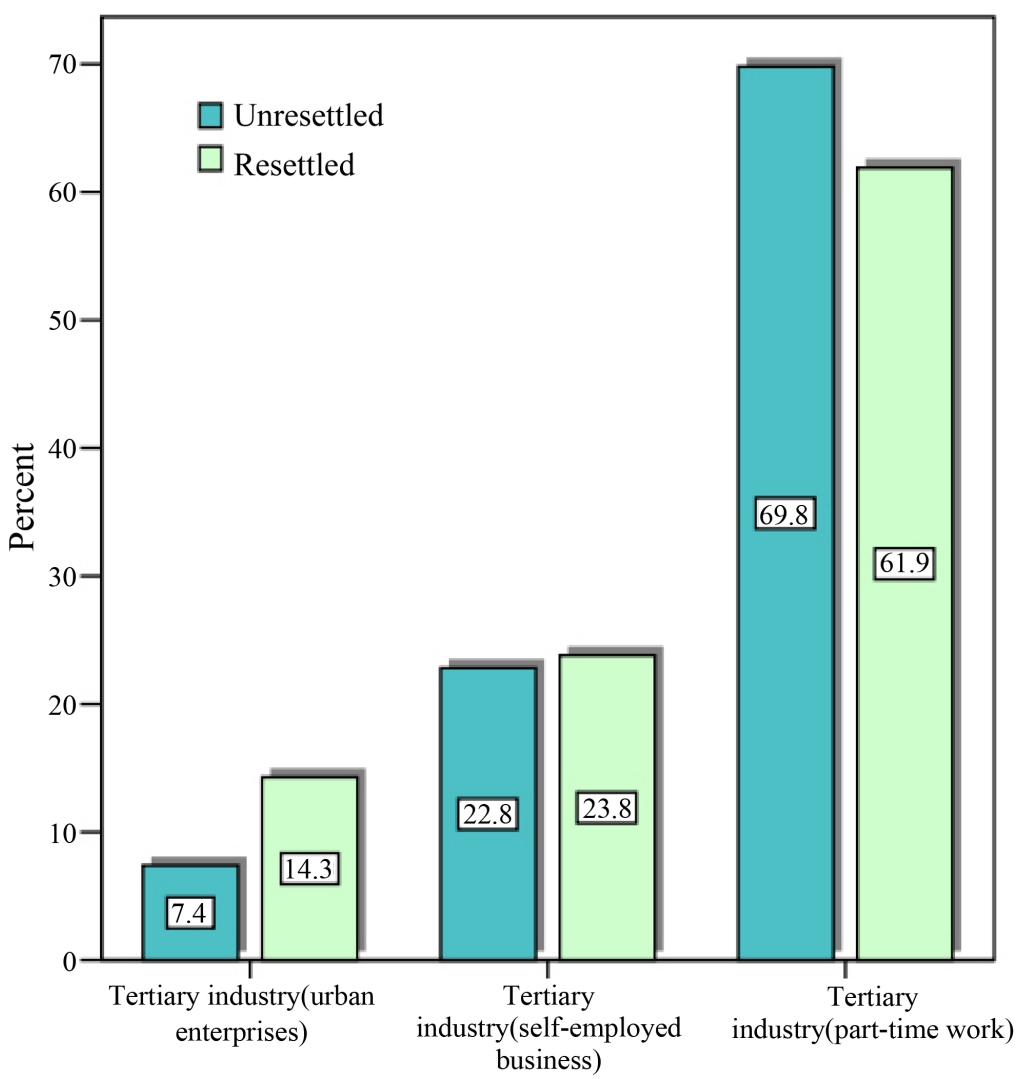

Figure 2. The situation involving the tertiary industry. 
The survey found that the farmers' perception of jobs has changed interestingly. Before resettlement, if farmers' incomes are mainly from part-time jobs, despite of instability, most of these farmers regard themselves as motor drivers, painters and porters, with farm work as a part-time job, or leaving part-time job blanked, although they own lands. However, after resettlement, farmers have been identified as citizens and have no farm land, but quite a large proportion of them still take themselves as farmers. This brings difficulty to our research, but reflects the great impact of acquisition of jobs on perception of identity [8].

\subsubsection{Income Situation}

After resettlement, the farmers' satisfaction with income has dropped remarkably. "Dissatisfaction" has raised from $21.3 \%$ to $33.3 \%$, while "satisfaction" has dropped from $25.2 \%$ to $14.3 \%$ (Figure 3 ).

\subsubsection{Education Situation}

Although the educational level has little change after settlement, it shows a rising trend as a whole. "Primary school or below" has dropped from $37.7 \%$ to $29.1 \%$; "Junior college" has risen from $2.8 \%$ to $6.8 \%$; "bachelor degree or above" has risen from $1.7 \%$ to $5.3 \%$ (Figure 4 ).

The improvement of educational level needs a long process, but a certain rising trend indicates that under the new non-agricultural environment, peasants' education consciousness has been enhanced, especially, they start to pay greater attention to the cultivation and education of their children.

\subsection{Facilities}

\subsubsection{Building Area of Residences}

Table 2 shows great difference in building area and building area per capita of

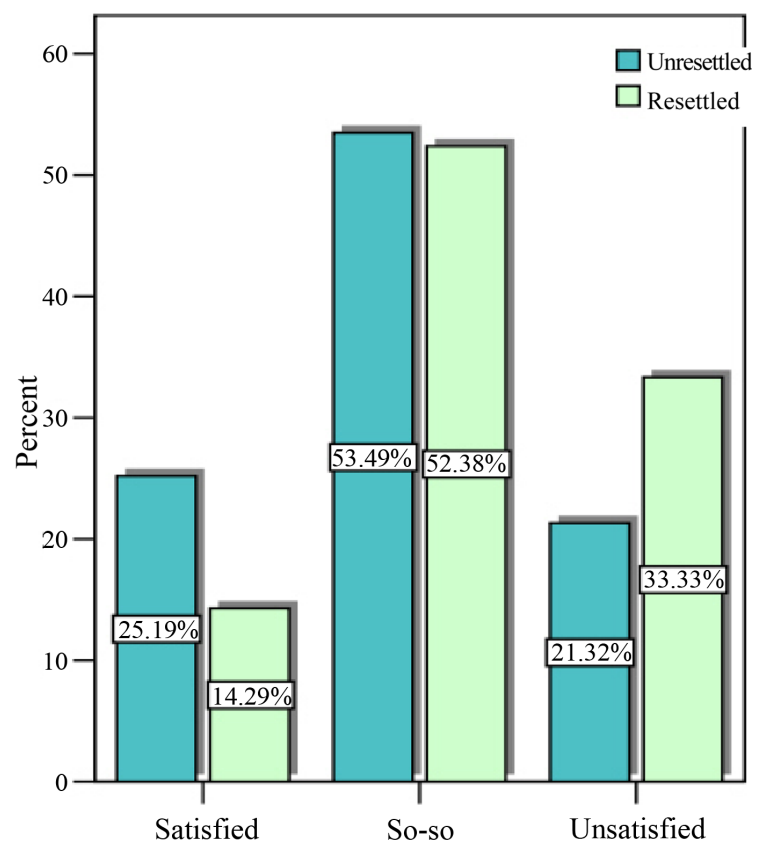

Figure 3. Satisfaction with family income. 


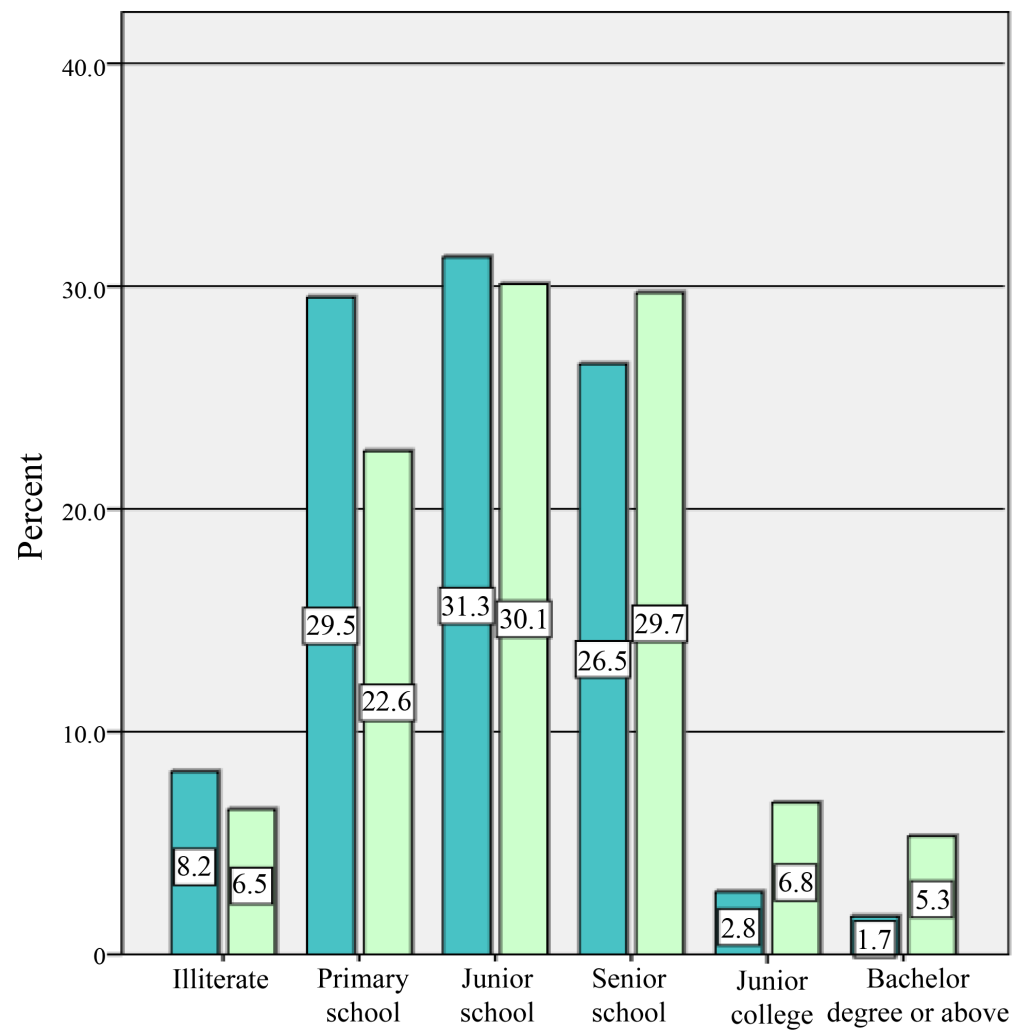

Figure 4. Educational level.

Table 2. Building area of unresettled households.

\begin{tabular}{ccc}
\hline & Building area $\left(\mathrm{m}^{2}\right)$ & Building area per capita $\left(\mathrm{m}^{2}\right)$ \\
\hline Average & 200.9 & 51.6 \\
Median & 184.9 & 45.8 \\
Standard deviation & 106.3 & 29.1 \\
\hline
\end{tabular}

unresettled households. Standard deviations are 106.3 and 29.1 respectively, showing obvious variations in residence level. Building area per capita is $51.6 \mathrm{~m}^{2}$, lower than the level after resettlement (the standard resettlement land per capita is $55 \mathrm{~m}^{2}$ ). However, after settlement, the area for self-use is not much and others are for leasing (62\% of population in the community are from outside), so the actual residence level drops.

\subsubsection{Satisfaction with Facilities}

After resettlement, residents' willingness is more scattered. Appeals for other outskirts and downtown have almost doubled, from $17.3 \%$ to $35.6 \%$ (Table 3 ). This shows the intensification of diversification, and meanwhile it shows reduction in residents' sense of belonging to their communities and the cohesion of communities after the settlement. Single and unified resettlement cannot satisfy the diversification. From this point of view, the current policy of unified resettlement is defective to some extent.

Reduction in "whatever" is also obvious, which reflects that based on requirements in education, occupation and living environment, residents have 
better understanding of the significance of residence, and higher demand on choosing.

\subsection{Willingness for Resettlement}

\subsubsection{Areas where Residents Are Most Willing to Live}

Residents tend to live in their villages or nearby areas. However, quite a lot people choose other outskirts, downtown etc. This reflects the diversity in residents' choices of future residence.

After resettlement, residents' willingness is more scattered. Appeals for other outskirts and downtown have risen from $17.3 \%$ to $35.6 \%$, by $100 \%$ (Figure 5).

Table 3. Table of satisfaction with facilities.

\begin{tabular}{|c|c|c|c|c|c|c|c|}
\hline & \multirow{2}{*}{ Item } & \multicolumn{3}{|c|}{ Unresettled area } & \multicolumn{3}{|c|}{ Resettled area } \\
\hline & & Satisfication (\%) & So so $(\%)$ & Dissatisfication (\%) & Satisfication (\%) & So so $(\%)$ & Dissatisfication (\%) \\
\hline \multirow{5}{*}{$\begin{array}{l}\text { Residential } \\
\text { environment }\end{array}$} & Residence & 40.3 & 47.3 & 12.4 & 22.6 & 57.1 & 20.2 \\
\hline & $\begin{array}{l}\text { Infrastructures (water, } \\
\text { electricity, gas, etc.) }\end{array}$ & 21.7 & 55.4 & 22.9 & 31.0 & 48.8 & 20.2 \\
\hline & Traffic (roads, buses, etc.) & 18.2 & 60.1 & 21.7 & 26.2 & 51.2 & 22.6 \\
\hline & Environmental health & 15.9 & 46.5 & 37.6 & 23.8 & 45.2 & 31.0 \\
\hline & $\begin{array}{l}\text { Service facilities (shopping, } \\
\text { medical, education, etc.) }\end{array}$ & 10.5 & 49.6 & 39.9 & 23.8 & 47.6 & 28.6 \\
\hline \multirow{3}{*}{$\begin{array}{l}\text { Social } \\
\text { environment }\end{array}$} & Neighborhood relationship & 62.8 & 34.9 & 2.3 & 50.0 & 45.2 & 4.8 \\
\hline & Social security & 21.7 & 56.6 & 21.7 & 23.8 & 52.4 & 23.8 \\
\hline & Organizational management & 5.0 & 65.5 & 29.5 & 14.3 & 56.0 & 29.8 \\
\hline
\end{tabular}

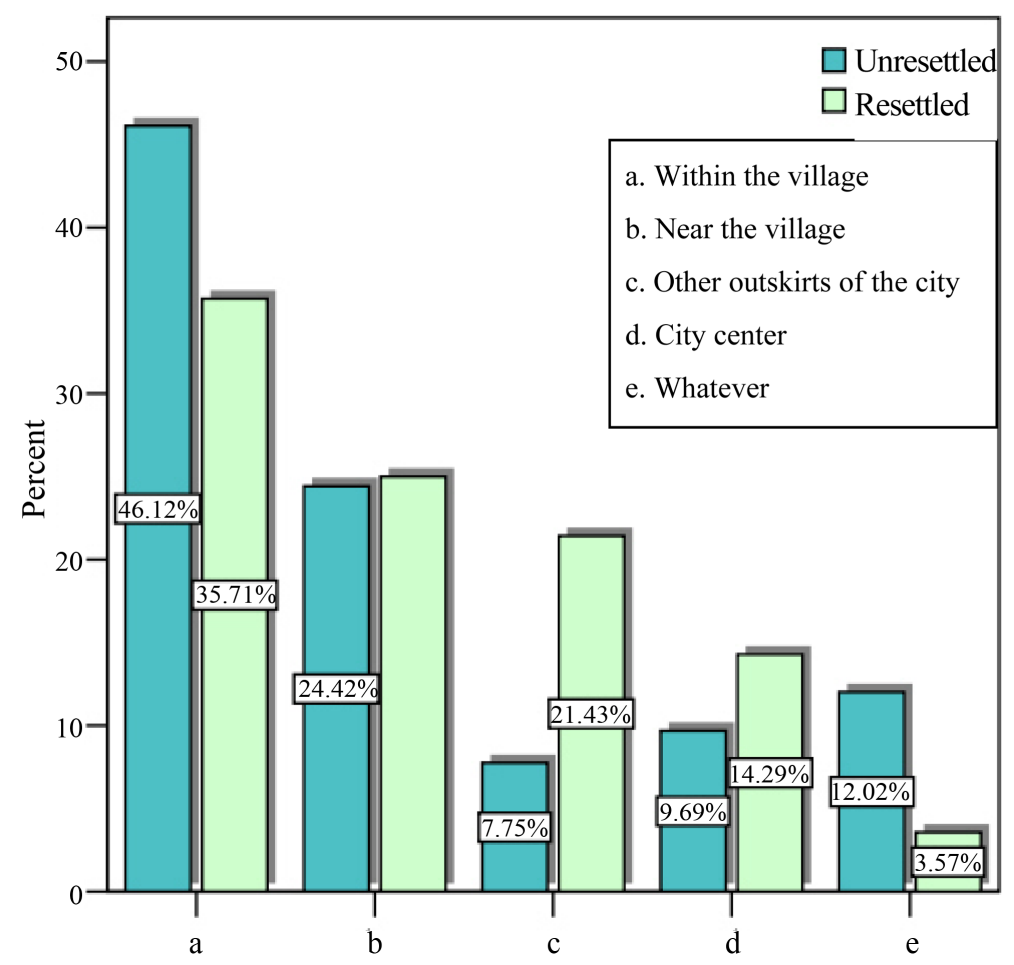

Figure 5. Areas residents most willing to live in. 
This, on the one hand, shows increasingly diversified choices and reduction in residents' sense of community belongingness and on the other hand, the cohesion of communities. Single and unified resettlement cannot satisfy the diversification. From this respective, the current policy of unified resettlement is defective to some extent.

Reduction in choosing "whatever" is also obvious (Figure 5), which reflects that based on requirements in education, occupation and living environment, residents' have achieved a better understanding of significance of residence, and higher demand for options.

\subsubsection{The Most Important Issues in Relocation}

Monetary compensation is regarded as the most important issue both before and after resettlement, followed by social welfare. Monetary compensation plus social welfare reached $81.4 \%$ before resettlement and $65.7 \%$ after it (Figure 6), which indicates that after resettlement the most important issues have been scattered, and tend to be more comprehensive and rational. Issues taking larger proportion after resettlement include children's access to education, vocational training, jobs and improvement in living environment.

\subsubsection{The Largest Obstacle to Job Hunting after Being Identified as Citizens}

Before and after resettlement, most villagers regard lack of occupational skills as the biggest obstacle for to hunting, which is of great significance for farmers' vocational training. There are still a considerable proportion of people thinking that the biggest obstacles are low salary, hard work, and bad working environment,

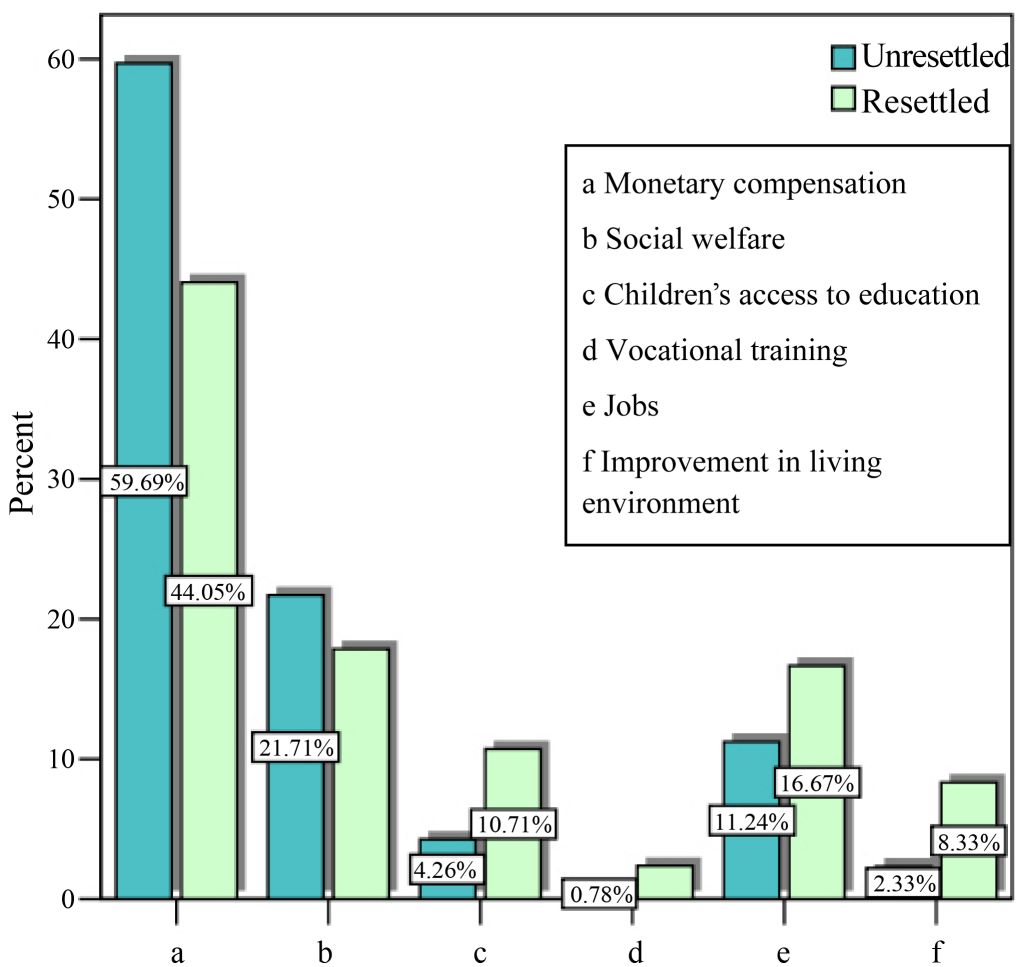

Figure 6. The most important issues in relocation. 
which indicates worker's dissatisfaction with their own working condition (Figure 7).

\section{Feature Analysis of Urbanization of Rural Settlement}

By summarizing the above-mentioned comparative analysis, and combining other investigation content, we can draw the following conclusion.

\subsection{Urbanization of Suburbs Presents a Passive Feature}

Subjectively, the suburban farmers do not have strong willingness to participate in urbanization [9]. It can be known from the investigation that the villagers who are not resettled have relatively higher degree of satisfaction with their life, either in the aspect of annual household income, residential status, or in vocational status. Therefore, they are unlike other rural labor forces who have relatively strong willingness of urbanization.

Objectively, they also lack of adaptability of urbanization, which mainly relates to educational degree and vocational skills. There is relatively greater difference in educational degree between them and the urban inhabitants. Although there is relatively high proportion for them to engage in by-business, the professions they engage in do not have strong technicality, they have small space for selection and are not stable.

\subsection{Resettlement Does Not Have Obvious Facilitation Effect on Conversion to Urbanization}

Resettlement does not make any difference in the aspects such as profession conversion, income increase, etc. Indeed, the degree of satisfaction is even decreased.

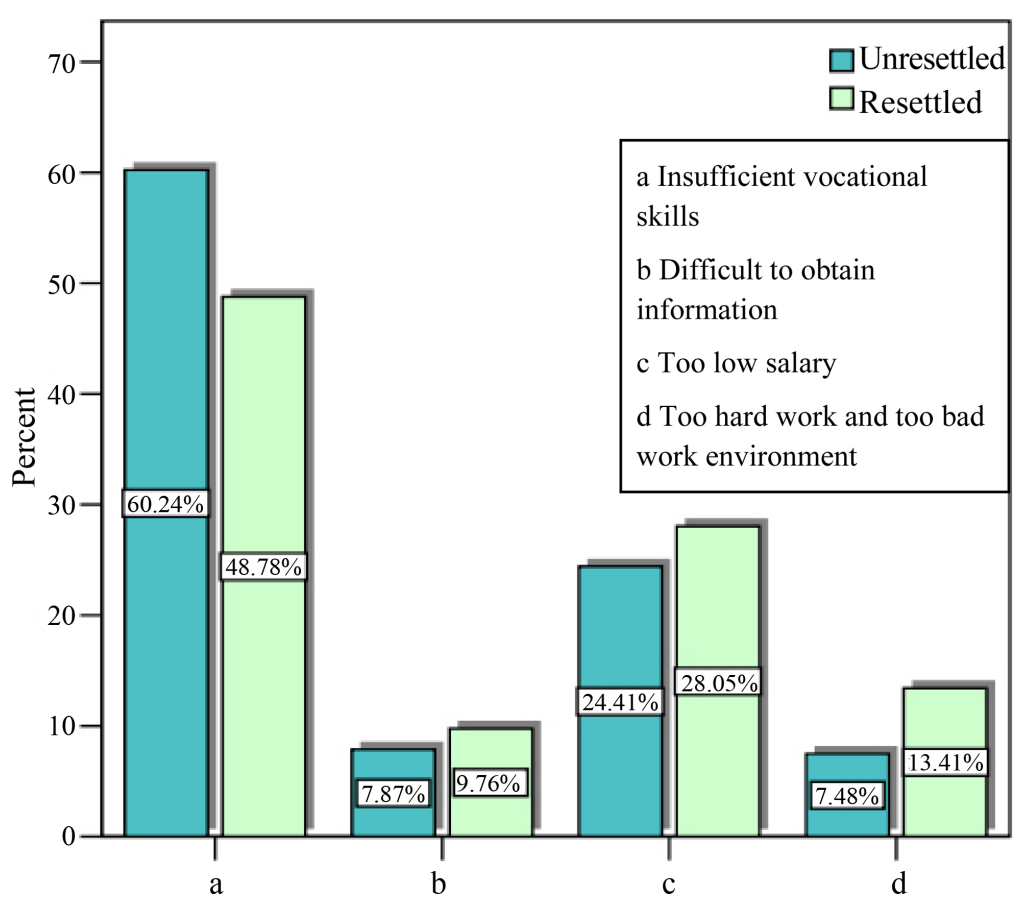

Figure 7. The biggest obstacle to seeking job after becoming an urban inhabitant. 
Meanwhile, because they are confronted with fierce competition of urban employment after resettlement, the pressure of survival has been increased. Lack of life guarantee and employment competition are the most disadvantageous problems after resettlement. On the other hand, on the issue of the biggest obstacle to seeking job, they think the work is too hard and the work environment is too bad, which indicates that the villagers have the tendency to feel awkward and shrink back when facing urban competition.

\subsection{The Foundation of the Original Community Disappears}

From the perspective of social space, different production relations generate different social relations. When production relation does not exist, social relation will also disappear. There is great difference between rural community and urban community. The rural community is dependent on self-sufficient smallscale peasant economy, which is an introversive and enclosed community with consanguinity as the bond. The urban community depends on market economy of division and cooperation of labour, which is an open and outgoing community with equal division of labour as the bond [10]. During the process of urbanization, although the original inhabitants still reside in the same geographical space, yet with loss of land, the first production means, the original relation of production formed in the engaged primary industry does not exist; and with profession conversion of the original inhabitants and immigration of new inhabitants, new relation of production is formed, and new social relation will displace the original social relation.

From the perspective of substance space, a community needs certain economic sources and institutional framework to maintain its substance environment. The repairing function of the rural community for living environment is mainly spontaneous and individual behaviour; whereas, collective decision is relatively less. During the process of urbanization, confronted with the supply of public goods, the community organization (group) established on the original economic base fails to timely realize adjustment of function and to establish new mechanism corresponding to the urban community [11].

\subsection{Invasion of Floating Population}

People generally consider that transformation of peasant to urban inhabitants is mainly a process of non-agriculturalization of profession and identity. However, in the present research, the author realizes that it is not a simple matter for farmers to be citizens only by giving them "registered permanent residence" and "safeguard" unilaterally by the government. The urban-rural gap actually exists. Since the day on which the land-lost peasant community is established, or the day on which it is incorporated into urban development area, it is destined to become a place of the lowest position in a city.

Due to the reasons such as residence choosing ability and selection of relatively familiar environment, rural resetting area has become the first choice for the majority of the floating population. In the case of the present research, the 
rental population before resettlement only takes $7.9 \%$; however, the rental population after resettlement reaches $61.8 \%$, becoming the main group of the community.

The above four features indicate that currently after urbanization of rural settlement, it presents not only an aspect of insufficient conversion and small transformation, but also an aspect of sudden change. Investigated from the perspective of community, there is an obvious tendency of "quasi community", which, if paid less attention to, is apt to generate various social problems.

\section{Suggestion of Countermeasures of Urbanization of Rural Settlement}

\subsection{We Should Be Fully Aware of the Challenge of Community of Low Position}

The classical social ecology holds that, there are different entry barriers in geographical space, and all orders of society will select residential location according to their own capabilities and inclination, which forms a differentiated pattern in the urban living space. The research of Chicago school indicates that in the Western migration city during the industrializing age, specific social ecological position location would be occupied by the corresponding social order.

Under the circumstance where social polarization phenomenon exists, there is a necessity for the low-positioned community to exist. The existence of the low positioned community reduces the cost of urbanization, and plays a role of buffer between city and village. On one hand, the city obtains substantial cheap labour force thereby, which promotes city development. On the other hand, it provides a cheap habitat for the rural labor force to enter the city, which makes it possible for the relatively poor countrymen to seek development in the city.

On the above-mentioned background, the existence of the community of low position has a solid foundation, the key being how the city selects and forms the low-positioned community among population mobility. The case of the present research is formed by the city government which leads land expropriation, compensation and then facing market under the mode of urban land economics. Due to the double layers of interest demand from the government and the developer, it is hard to guarantee the interest of the land-lost farmers, thus it is difficult to avoid lowering tendency of the position of the rural urbanization community.

Under the new situation in the future, the system of ownership of collective land in rural areas may directly face market, which brings new opportunity to the land-lost farmers, so that the rural urbanization community is no longer restricted to the confinement of low position. Directly facing market mainly solves the financial matter of urbanization for the farmers [12]; however, new challenges become prominent: the first being organization, management and operation ability in the urbanization system engineering; secondly, the self-quality and adaptive faculty of urbanization of farmers. It requires to study a whole set of coping strategies: on the one hand, introducing external force to assist and pro- 
mote; on the other hand, reinforcing the self-quality and ability of farmers, both of which are equally important.

\subsection{We Should Pay Full Attention to the Soft Environment Construction}

During the process of constructing rural urbanization community, we should lay emphasis on multiple kinds of intangible environment construction, so as to avoid the tendency of the rural urbanization community to become "quasi community". The most important thing for soft environment construction is the attention to "human being". We should be convinced of the radical difference between original villagers and urban inhabitants [13]; while ensuring the living environment, public supporting facilities and economic benefits of the villagers, we will establish the community management, vocational training, and job-introduction agency, and bring villagers into the social security system, such as urban medical services, pension and employment.

In addition, we will draw lessons from the community construction, make farmers take initiative to participate in the construction process under the guidance and organization of professional institutions, which is also an effective method to promote the fusion process between farmers and the city, and reduce subsequent conflicts. Since 1960s, theoretical and practical evolution from the bottom up appeared in the field of urban living environment construction in some western countries, and the outcome thereof greatly promoted the "community construction", and encouraged public participation as well as community cooperation during the living environment construction. Currently, a series of concepts such as community planning, neighborhood conservation, community development, inhabitant self-service, user participation, community cooperation, community technical assistance, etc. have gained extensive response and support from the United Nations and many countries all over the world.

Actually, community-level democracy in rural areas of China is carried out thoroughly, which provides solid foundation for the development of community construction. The question is that more professional, comprehensive and meticulous guidances are required by farmers to participate in the community construction, which proposes a higher demand for relevant planning making and policy formulation. Relevant planning and policy should be on material level and be on social and economic level to great extent. We need to make a comprehensive arrangement for habitancy, livelihood and work after the urbanization of villagers. The form of planning making should also be converted from a procedure coming from above to coming from below; otherwise, it is hard to become comprehensive and reasonable.

Under the existing urbanization mode with urban land expropriation as the leading factor, the above objective is very difficult to be achieved. With deepening the reform of collective land ownership system, when the urbanization no longer takes the city as the single leading factor, the above-mentioned mode and planning may be truly realized. 


\section{Conclusions}

During the urbanization process of rural settlement in suburbs of China, there are two different forms, namely original villages and resettled areas. This paper selects two kinds of settlements in the same region for comparative analysis, and discovers that the aspects of employment state and self-occupation cognition change obviously, and the income satisfaction decreases after urbanization on the contrary, while the facility satisfaction increases generally; however, the satisfaction of neighborhood relationship descends obviously. The selection of habitat after urbanization tends to be more open and diversified, and the cognition of important issues becomes more comprehensive and rational. The problems such as the access to education of children, vocational skills training, employment opportunities and improvement of living environment attract more attention. On the basis of comparative analysis, this paper further summarizes four features of suburb urbanization, i.e. passivization, non-obvious urbanization conversion, disappearance of original community base and invasion of floating population.

Based on the above cognition, this paper holds the opinion that during the process of urbanization of suburban rural settlement, on one hand, multiple measures should be adopted so as to avoid to fall into the trap of low-positioned community; on the other hand, the attention to "human beings" should be strengthened, and intangible environment construction should receive full attention; meanwhile, the participation of farmers should be reinforced during the process of community construction and formulation of relevant planning and policy.

\section{References}

[1] Fan, F. (2013) Exploration and Analysis of Feasible Path for the Reform of Land Property Right in Rural China-Land Right Expansion under Limited Land Privatization and Collective Ownership System. Rural Economy and Science and Technology, 4, 35-37.

[2] Wei, L. and Yan, X. (2005) "Villages in City": Transformation on the Premise of Existence-Feasible Mode of "Villages in City" Transformation. Urban Planning, 7, 9-13.

[3] Wang, M., Lin, X. and Ning, Y. (2012) External Population, Temporary Residence and "Villages in City" Transformation-Survey Report from Shanghai. Urban Planning, 7, 73-80.

[4] Zhu, Y. (2004) Changing Urbanization Processes and in Situ Rural-Urban Transformation: Reflections on China's Settlement Definitions. New Forms of Urbanization: Beyond the Urban-Rural Dichotomy, 207-228.

[5] Zhang, J. and Zhao, W. (2007) Analysis on the Development and Significance of "Villages in City" in the Dual Regulation Environment. Urban Planning, 1, 63-67.

[6] Yang, J. and Chen, C. (2013) Current Situations and Features of Family-Oriented Floating Population: Analysis on the Features of Floating Process. Population and Development, 3, 2-13.

[7] Zhu Y. (2000) In Situ Urbanization in Rural China: Case Studies from Fujian Province. Development and Change, 2, 413-434. 
https://doi.org/10.1111/1467-7660.00160

[8] Yao, J. (2011) Analysis of Obstacles of Land-lost Peasant Identity RecognitionAnalysis Based on Relevant Investigation Data of the Yangtze River Delta. Urban Problem, 8, 93-99.

[9] Yu, J., Yang, Z. and Xiong, H. (2013) A Comparative Study on Active Urbanization and Passive Urbanization. Urban Insight, 1, 142-149.

[10] Castillo and Jose, M. (2000) Urbanisms of the Informal: Spatial Transformations in the Urban Fringe of Mexico City. Dissertation Abstracts International, 61, 1643.

[11] Lin, X. and Zhao, K. (2006) The Role of the "Management Communications" Course in Enhancing. Journal of China Agricultural University (Social Sciences Edition), 4, 67-70.

[12] Zhao, X. and Zhang, J. (2013) The Research on the Pilot Program of Exchanging Property of Suburban Collective Ownership Land for Equity. Scientific Development, 5, 24-27.

[13] Zhang, X. (2013) Social Adaption of Land-Requisitioned Farmers: Based on Social Exclusion Theory. South Architecture, 1, 24-27.

\section{Scientific Research Publishing}

Submit or recommend next manuscript to SCIRP and we will provide best service for you:

Accepting pre-submission inquiries through Email, Facebook, LinkedIn, Twitter, etc. A wide selection of journals (inclusive of 9 subjects, more than 200 journals)

Providing 24-hour high-quality service

User-friendly online submission system

Fair and swift peer-review system

Efficient typesetting and proofreading procedure

Display of the result of downloads and visits, as well as the number of cited articles

Maximum dissemination of your research work

Submit your manuscript at: http://papersubmission.scirp.org/

Or contact jss@scirp.org 